\title{
Variations in lead, cadmium, arsenic, and mercury concentrations during honeybee wax processing using casting technology
}

\author{
Ivana Tlak Gajger ${ }^{1}$, Marina Kosanović1 ${ }^{\text {, Nina Bilandžić }}{ }^{2}$, Marija Sedak², and Bruno Čalopek ${ }^{2}$ \\ Department for Biology and Pathology of Fish and Bees, University of Zagreb Faculty of Veterinary Medicinel, \\ Department of Veterinary Public Health, Laboratory for Residue Control, Croatian Veterinary Institute ${ }^{2}$, Zagreb, \\ Croatia
}

[Received in February 2016; CrossChecked in February 2016; Accepted in July 2016]

\begin{abstract}
Beeswax foundations are a necessary material in intensive modern beekeeping. Heavy metals can accumulate in these foundations for decades, as it is a common beekeeping practice to recycle wax. Beeswax samples were analysed using GFAAS for $\mathrm{As}, \mathrm{Cd}, \mathrm{Pb}$, and $\mathrm{Hg}$ concentrations during the production of beeswax foundations using casting technology with a prolonged cooling and sedimentation phase. Significant differences were determined in the concentrations of As, $\mathrm{Cd}, \mathrm{Pb}(\mathrm{p}<0.01$, all), and $\mathrm{Hg}(\mathrm{p}<0.05)$ between the three levels of wax in a double-walled steel casting container and comb foundations (CF) during the processing stage. Concentrations $\left(\mathrm{mg} \mathrm{kg}^{-1}\right)$ of the examined metals in comb foundations as the final product ranged as follows: As $0.01-0.88 ; \mathrm{Cd} 1.26-3.55 ; \mathrm{Pb} 82.5-171$, and $\mathrm{Hg} 0.29-1.46$. All examined element concentrations demonstrated similar distribution and ratio in different layers, ranging from the lowest concentrations in layers from which wax material is used for comb foundations as the final product, to the highest concentrations in sedimented layer, which represents waste. The obtained results suggest that the described method could effectively eliminate a significant amount of heavy metals from the initial material used for the production of new beeswax foundations.
\end{abstract}

KEY WORDS: arsenic; beeswax; cadmium; comb foundations; lead; mercury

Beeswax is a natural honeybee product. It is an extremely complex mixture consisting mainly of esters of higher fatty acids, alcohols, hydrocarbons, proteins, and other minor substances (1-2). Beeswax is primarily used in beekeeping to produce comb foundations but also in the chemical, cosmetic, pharmaceutical, and food industries. In hives, it is vital for the honeybee colony, as it is a construction material for comb cells where nectar and honey are stored (3). Successful comb management is crucial for beekeeping practice and quality, and the sensory properties of beeswax depend greatly on production methods (4). The production or processing of beeswax comb foundations has been described elsewhere (5).

Wax, along with other apian products, can be a useful tool for collecting information about environmental contamination with toxic metals (6-10). Honey could be considered a primary bio-indicator of pollution and therefore used to assess the presence of metals and pesticides in soil, water, and plants (11). Beeswax combs represent a sink or an outlet for many environmental contaminants and, when in the hive for toxins as well, because of a specific lipid-based chemical composition (3).

Correspondence to: Ivana Tlak Gajger, Department for Biology and Pathology of Fish and Bees, University of Zagreb, Faculty of Veterinary Medicine, Heinzelova 55, 10000 Zagreb,Croatia; e-mail: ivana.tlak@vef.hr
As, $\mathrm{Cd}, \mathrm{Pb}$, and $\mathrm{Hg}$ are the main toxic heavy metals in environmental pollution that can contaminate honeybee products, primarily nectar and honeydew. Due to the order and social activity of foragers and house bees, combs and the inside of the hives can also be contaminated (12). The presence of these metals depends on the environmental pollution of air, water, and soil $(13,14)$ and may cause a wide range of toxic effects, including gastrointestinal, muscular, reproductive, neurological or behavioural effects. Such adverse health effects have been previously documented in birds and mammals, especially for $\mathrm{Pb}$ (15-17). Discharge of this highly toxic effluent can seriously impact the environment, as these metals cannot be destroyed or degraded, and their accumulation through the food chain leads to ecological issues with dire consequences $(18,19)$.

Pursuant to the European legislation, beeswax specification values were set to $5 \mathrm{mg} \mathrm{kg}^{-1}$ for $\mathrm{Pb}, 3 \mathrm{mg} \mathrm{kg}^{-1}$ for As and $1 \mathrm{mg} \mathrm{kg}^{-1}$ for $\mathrm{Hg}$ (20). The FAO/WHO Expert Committee on food additives also set a concentration of $2 \mathrm{mg} \mathrm{kg}^{-1}$ for $\mathrm{Pb}$ in wax, and proposed a maximum residue limit (MRL) for the $\mathrm{EU}$ of $1 \mathrm{mg} \mathrm{kg}^{-1}$ (21-22). The committee of the European Food Safety Authority (EFSA) (23) recommended that the specification for $\mathrm{Pb}$ should be set as low as possible, due to its possible toxic effects.

There are very few studies on the heavy metal contamination of beeswax (24), and data on its influence on comb foundation 
quality, as well as the correlations with the rearing and biological characteristics of honeybee brood in contaminated combs are insufficient. It is not known how effective the production of casting comb foundations with a long sedimentation and cooling period is in reducing heavy metal concentrations. In everyday beekeeping conditions, beekeepers collect old, dark, and destroyed combs during the active beekeeping season and then deliver the total amount of wax to the craft unit. Also, because most beekeepers do not have enough collected wax for one round of its processing, commonly few beekeepers join raw material together in the form of wax sheaves for annual comb foundation remount. In the processing stage of beeswax, after melting and homogenisation, several layers of wax are deposited within heated water containers made of high-grade steel during a 48hour sedimentation period. This step in processing is necessary for an additional cleansing of melted wax. Impurities sink to the lowest part of the wax and must be removed from the container after the sedimentation period, and only the pure upper layers of wax should be used for production of new comb foundations.

The objective of this study was to determine and compare the concentrations of $\mathrm{As}, \mathrm{Cd}, \mathrm{Pb}$, and $\mathrm{Hg}$ from different layers of melted wax in containers during the processing and production of wax comb foundations, including comb foundations as the final product.

\section{MATERIALS AND METHODS}

\section{Beeswax samples}

A total of 24 samples of melted wax were collected from three double-wall heatable steel water containers, $200 \mathrm{~L}$ volume each, during the comb foundation production. Samples were taken 48 hours after melting, homogenisation, sterilisation of beeswax at $125^{\circ} \mathrm{C}$ for one hour, and the sedimentation process. During sedimentation, melted wax was kept at an automatically set temperature of $75^{\circ} \mathrm{C}$.

The levels of wax in the container where samples were taken are shown in Figure 1. A long handled grab was used to sample the surface layer (L1). The container had two pipes at different levels with a $7 \%$ elevation difference. The lowest level faucet served first to sample dark sediment (L3) and then lighter wax from the second layer (L2). Beekeepers usually deliver raw wax material in the form of beeswax sheets to a wax production craft unit. Therefore, when using containers such as this, from the higher level faucet, the final material for the comb foundation is slided directly onto a cooled roller that prints the comb foundations. In our case, prior to the contact with the roller, the last sample of the final wax material was taken ( $\mathrm{CF}$ - material for the comb foundations). Upon collection, all wax samples (100 g) were placed into clean plastic containers, labelled, and transferred to the laboratory and kept at $4-8{ }^{\circ} \mathrm{C}$ until analysis.

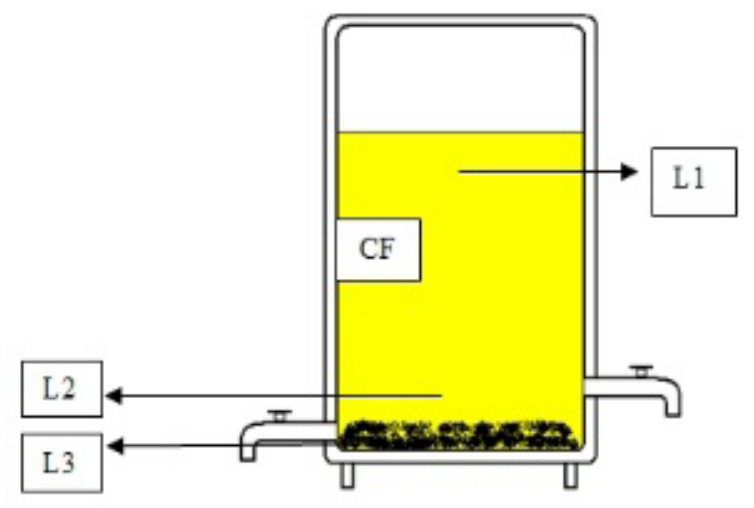

Figure 1 Wax sampling levels in a double-walled steel container 48 hours after the processing of raw material, using a casting method with a prolonged cooling and sedimentation period

\section{Reagents}

All reagents were of analytical reagent grade, $\mathrm{HNO}_{3}, \mathrm{H}_{2} \mathrm{O}_{2}$, and $\mathrm{HCl}$ (Analytical Grade, Kemika, Croatia). Ultra-pure water (Milli-Q Millipore, 18.2 M M $\Omega / \mathrm{cm}$ resistivity) was used for all dilutions. Plastic and glassware were cleaned by soaking in diluted $\mathrm{HNO}_{3}(1 / 9, \mathrm{v} / \mathrm{v})$ and rinsed with distilled water prior to use. Calibrations were prepared with element standard solutions of $1000 \mathrm{mg} \mathrm{L}^{-1}$ of each element supplied by Perkin Elmer. Stock solution was diluted in $\mathrm{HNO}_{3}(0.2 \%)$. Matrix modifiers (all Perkin Elmer, USA) in each atomisation were: for $\mathrm{Cd} 0.005 \mathrm{mg} \mathrm{Pd}\left(\mathrm{NO}_{3}\right)_{2}$ and $0.003 \mathrm{mg} \mathrm{Mg}\left(\mathrm{NO}_{3}\right)_{2}$, for $\mathrm{Pb}$ $0.050 \mathrm{mg} \mathrm{NH} \mathrm{H}_{2} \mathrm{PO}_{4}$ and $0.003 \mathrm{~g} \mathrm{Mg}\left(\mathrm{NO}_{3}\right)_{2}$, and for As $0.01 \mathrm{mg} \mathrm{Pd}\left(\mathrm{NO}_{3}\right)_{2}$ and $0.005 \mathrm{mg} \mathrm{Mg}\left(\mathrm{NO}_{3}\right)_{2}$.

\section{Microwave digestion}

Samples ( $2 \mathrm{~g}$ ) were digested with $5 \mathrm{~mL} \mathrm{HNO}_{3}(65 \% \mathrm{v} / \mathrm{v})$, $1 \mathrm{~mL} \mathrm{H}_{2} \mathrm{O}_{2}(30 \% \mathrm{v} / \mathrm{v})$ with a microwave oven. A blank digest was carried out in the same way. The Multiwave 3000 microwave closed system (Anton Paar, Germany) was used for sample digestion. The digestion program first began at a potency of $1200 \mathrm{~W}$ and was then ramped for $10 \mathrm{~min}$, after which the samples were held at $1200 \mathrm{~W}$ for $10 \mathrm{~min}$. The second step began at a potency of $0 \mathrm{~W}$ and was held as such for $15 \mathrm{~min}$. Digested samples were diluted to a final volume of $50 \mathrm{~mL}$ with double deionised water.

Samples were run in batches that included two replicates of an individual sample, blanks, a standard for the calibration curve, and two spiked specimens. All metal concentrations were determined on a wet weight basis as $\mathrm{mg} \mathrm{kg}^{-1}$. Detection limits (LOD) were determined as the concentration corresponding to three times the standard deviation of ten blanks and were found to be $\left(\mathrm{mg} \mathrm{kg}^{-1}\right)$ : As 0.01, Cd 0.0004, Pb $0.005, \mathrm{Hg} 0.0005$.

To calculate the recovery percentages, five wax samples spiked with known amounts of element analytical standards were processed as follows $\left(\mathrm{mg} \mathrm{kg}^{-1}\right)$ : for As 0.02 ; for $\mathrm{Cd} 0.02$, for $\mathrm{Hg} 0.02$, for $\mathrm{Pb} 0.05$. The quality of data showed good 
Table $1 \mathbf{a}$, $\mathbf{b}$ Instrumental conditions for the determination of $\mathrm{Pb}, \mathrm{Cd}$, and As by graphite furnace atomic absorption spectrometry (GFAAS) and Hg, using a mercury analyser, in beeswax samples

Table la

\begin{tabular}{|c|c|c|c|}
\hline \multicolumn{4}{|c|}{$\begin{array}{l}\text { Conditions for graphite furnace atomic absorption spectrometry (GFAAS) and heating program } \\
\text { temperature }{ }^{\circ} \mathrm{C} \text { (ramp time (s), hold time (s)) }\end{array}$} \\
\hline & As & Cd & $\mathbf{P b}$ \\
\hline Wavelength (nm) & 193.7 & 228.8 & 283.3 \\
\hline Argon flow $\left(\mathrm{mL} \mathrm{min}^{-1}\right)$ & 250 & 250 & 250 \\
\hline Sample volume $(\mu \mathrm{L})$ & 20 & 20 & 20 \\
\hline Modifier volume $(\mu \mathrm{L})$ & 5 & 5 & 5 \\
\hline Drying 1 & $110(1,30)$ & $110(1,30)$ & $110(1,30)$ \\
\hline Drying 2 & $130(15,30)$ & $130(15,30)$ & $130(15,30)$ \\
\hline Ashing & $1600(10,20)$ & $700(10,20)$ & $900(10,20)$ \\
\hline Atomisation & $2000(0,5)$ & $1550(0,5)$ & $1850(0,5)$ \\
\hline Cleaning & $2450(1,3)$ & $2450(1,3)$ & $2450(1,3)$ \\
\hline
\end{tabular}

Table $1 \mathrm{~b}$

\begin{tabular}{ll}
\hline & Conditions for mercury analyser \\
\hline & Hg \\
\hline Wavelength (nm) & 253.65 \\
\hline Drying time (s) & 60 \\
\hline Decomposition time (s) & 150 \\
\hline Wait time (s) & 45 \\
\hline Weight / volume of sample & $100 \mathrm{mg} 100 \mathrm{~mL}^{-1}$ \\
\hline Working range & $0.05-600 \mathrm{ng}$ \\
\hline
\end{tabular}

accuracy, with calculated recoveries for elements (\%): As 93.5, $\mathrm{Cd}$ 95.7, Hg 98.2, Pb 97.8.

\section{Analysis of metals}

The analyses of $\mathrm{As}, \mathrm{Cd}$, and $\mathrm{Pb}$ were conducted at 193.7, 228.8, and $283.3 \mathrm{~nm}$ by graphite furnace-atomic absorption spectroscopy using an AAnalyst 600 (Perkin Elmer, USA). Mercury levels in wax samples were quantified without acid digestion using AMA-254 (Advanced Mercury Analyser, Leco, Poland), which employs direct combustion of the sample in an oxygen-rich atmosphere. The instrumental settings and optimising temperature programs of the graphite spectrometer and mercury analyser are summarised in Tables $1 \mathrm{a}$ and $1 \mathrm{~b}$.

\section{Statistical analysis}

Statistical analyses were performed using STATA ${ }^{\circledR} 13.1$ (StataCorp LP ${ }^{\circledR}, \mathrm{USA}$ ). Concentrations of $\mathrm{Pb}, \mathrm{As}, \mathrm{Cd}$, and $\mathrm{Hg}$ in wax samples were expressed as the minimum and maximum concentrations, median, mean \pm standard deviation (SD). The Shapiro-Wilk test was used for the determination of data distribution and the Kruskal-Wallis test for the determination of differences between the concentrations of elements in wax samples. Statistically significant differences were expressed as the level of probability $\leq 0.05$ and 0.01 .

\section{RESULTS AND DISCUSSION}

The results for heavy metal concentrations in wax samples are given in Table 2. Significant differences in the concentrations of As, $\mathrm{Cd}, \mathrm{Pb}(p<0.01$, all), and $\mathrm{Hg}(p<0.05)$ were determined between the four observation levels for wax samples. The highest concentrations of all four examined metals were determined in the wax samples taken at the sediment level (L3), which can be considered the concentrations in raw material, and the lowest were detected in the surface (L1) and middle layers (L2), which is where most of the material for the final product, the comb foundation (CF), is located. The concentrations in L3 were three times higher than in L2, and a hundred times higher than in L1. The concentrations of As decreased in the following order: $\mathrm{L} 3>\mathrm{L} 2>\mathrm{L} 1>\mathrm{CF}$. L1 and L2 concentrations of $\mathrm{Cd}$ were approximately fifty times lower than the concentration in L3. The concentrations of $\mathrm{Cd}$ increased in the following order: $\mathrm{L} 2<\mathrm{L} 1<\mathrm{CF}<\mathrm{L} 3$, and they were about fifty times higher in L3, than in L1, L2, or CF. Cadmium concentrations found in L1, L2, and CF observation points were lower or similar to published data (25). Mercury concentrations from L1, CF, and L2 were about fifteen times lower than in L3. The content of harmful metals (As, Hg) was within the maximum tolerable levels according to the regulations for nutritional products or additives (21-23), with the exception of $\mathrm{Pb}$. The obtained $\mathrm{Pb}$ concentrations appear very high, and although the concentrations from L1 and L2 were approximately a hundred times lower than in L3, high amounts were detected in CF. This fact is difficult to discuss due to a lack of detailed data on wax manipulation and storage prior to its delivery to the wax production craft unit. Also, the measured $\mathrm{Pb}$ concentrations were higher than the previously reported results on the mineral content in honeybee products within the frame of environmental pollution monitoring (13, 
Table 2 Concentrations of heavy metals in beeswax samples determined at four observation levels, during the production of wax foundations using a casting method with a prolonged cooling and sedimentation period

\begin{tabular}{|c|c|c|c|c|c|}
\hline $\begin{array}{l}\text { Element } \\
\left(\mathrm{mg} \mathrm{kg}^{-1}\right)\end{array}$ & Statistics & $\begin{array}{c}\text { L1 } \\
\begin{array}{c}\text { (surface level) } \\
n=6\end{array}\end{array}$ & $\begin{array}{c}\mathrm{L} 2 \\
\begin{array}{c}\text { (middle level) } \\
\mathrm{n}=6\end{array}\end{array}$ & $\begin{array}{c}\text { L3 } \\
\substack{\text { (sediment level) } \\
n=6}\end{array}$ & $\begin{array}{c}\text { CF } \\
\begin{array}{c}\text { (comb foundation) } \\
n=6\end{array}\end{array}$ \\
\hline \multirow{3}{*}{$\mathrm{As}^{* *}$} & Mean \pm SD & $0.69 \pm 1.06$ & $2.69 \pm 3.12$ & $70.2 \pm 49.0$ & $0.15 \pm 0.36$ \\
\hline & Median & 0.005 & 1.56 & 67.1 & 0.01 \\
\hline & Min-Max & $0.005-2.14$ & $0.005-6.96$ & $19.3-144$ & $0.01-0.88$ \\
\hline \multirow{3}{*}{$\mathrm{Cd}^{* *}$} & Mean \pm SD & $1.61 \pm 0.47$ & $1.47 \pm 0.46$ & $84.0 \pm 69.1$ & $2.24 \pm 0.83$ \\
\hline & Median & 1.68 & 1.35 & 75.4 & 2.42 \\
\hline & Min-Max & $0.92-2.26$ & $1.02-2.16$ & $16.8-202$ & $1.26-3.45$ \\
\hline \multirow{3}{*}{$\mathrm{Hg}^{*}$} & Mean \pm SD & $1.20 \pm 1.36$ & $0.67 \pm 0.23$ & $9.50 \pm 15.1$ & $0.83 \pm 0.39$ \\
\hline & Median & 0.52 & 0.73 & 1.49 & 0.78 \\
\hline & Min-Max & $0.33-3.79$ & $0.29-0.87$ & $0.99-38.9$ & $0.29-1.46$ \\
\hline \multirow{3}{*}{$\mathrm{Pb}^{* *}$} & Mean \pm SD & $58.1 \pm 21.5$ & $48.0 \pm 19.1$ & $6312 \pm 4043$ & $115 \pm 35.1$ \\
\hline & Median & 65.3 & 54.0 & 6438 & 105 \\
\hline & Min-Max & $28.1-82.2$ & $17.3-66.3$ & $1338-10802$ & $82.5-171$ \\
\hline
\end{tabular}

Statistically significant differences between the elements: ${ }^{*} \mathrm{p}<0.05,{ }^{*} \mathrm{p}<0.01$

25). These authors stated that dust fallout could contain significant amounts of $\mathrm{Pb}$ and $\mathrm{Cd}$, which could be linked to the manner of storage of raw wax. There is a lack of knowledge about the possible negative effects of the examined metals on honey brood and also the need for beeswax quality control regarding contaminants and adulteration (26).

Studies on heavy metal contamination of honeybees, honey or pollen are well documented $(27,10,28,29)$. However, beeswax is analysed very rarely, likely due to the fact that it is not consumed. From another aspect, honey ripens in wax combs, and may later be consumed or used in medicine or cosmetics. Also, comb contamination with heavy metals could likely affect honeybee brood development, after-emergence vitality, queen productivity or longevity of adult bees. For all these physiological parameters, pesticides have been proven to have a negative effect (30-33). Heavy metal concentrations are not routinely examined in beeswax foundation production. There is a probability they will be washed during the process of comb melting but without sufficient knowledge of the ratio. Moreover, heavy metal contaminants resist the wax melting temperature. Therefore, they can accumulate for decades, as it is a common beekeeping practice to recycle wax almost continuously in the form of comb foundations, upon which honeybees construct a complete comb. Contaminants from the environment can reach the raw materials of bee products and can be transported to the hive as a consequence of bees' physiological activities (34-35). It is also known that pesticides and acaricides used in regular beekeeping practices, or other fat soluble and persistent substances, can easily accumulate within (24). Recently, Reddy et al. (36) concluded that honeycomb biomass is an environmentally friendly and attractive option for removing heavy metal ions from water or wastewater.

Stratification of melted wax during a prolonged cooling and sedimentation period could have an effect on metal precipitation in the lower wax layers. Although the wax in the upper layers is not completely free of heavy metal traces, it could be efficiently washed using the described technology. In this study, all examined element concentrations demonstrated a similar distribution and ratio in different layers, ranging from the lowest concentrations in L1 and L2, from which wax material is used for $\mathrm{CF}$ as the final product, to the highest concentrations in L3, which represents waste. Although a more detailed study is necessary, it can be stated that in the light of these preliminary results, the concentrations of the examined elements in CF are significantly lower than in the initial wax material, with the exception of $\mathrm{Pb}$. The obtained results suggest that the described method could effectively eliminate a significant amount of heavy metals from the initial material used for the production of new beeswax foundations and its use can be recommended. Generally, beeswax samples should be analysed more often during wax processing season, with respect to toxic metals contamination.

\section{Acknowledgments}

The authors express their sincere gratitude to all beekeepers for their cooperation. This study was funded by the Ministry of Agriculture, Croatia, VIP Project No. 2013-12-62.

\section{REFERENCES}

1. Tulloch AP. Beeswax - composition and analysis. Bee World 1980;61:47-62. doi: 10.1080/0005772X.1980.11097776

2. Aichholz R, Lorbeer E. Investigation of combwax of honeybees with high-temperature gas chromatography and high-temperature gas chromatography - chemical ionization mass spectrometry. I. High-temperature gas chromatography. J Chromat A 1999;855:601-15. doi: 10.1016/S00219673(99)00725-6

3. Buchwald R, Breed MD, Bjostad L, Hibbard BE, Greenberg AR. The role of fatty acids in the mechanical properties of beeswax. Apidologie 2009;40:585-94. doi: 10.1051/ apido/2009035 
4. Bogdanov S. Beeswax: Production, Properties Composition and Control Bee Product Science 2009 [displayed 5 July 2016]. Available at https://www.researchgate.net/ publication/237411324_Beeswax_Production_Properties Composition_and_Control

5. Coggshall WL, Morse RA. Beeswax. Production, Harvesting and Products. Ithaca, (NY): Wicwas Press; 1984.

6. Przybyłowski P, Wilczynska A. Honey as an environmental marker. Food Chem 2001;74:289-91. doi: 10.1016/S03088146(01)00153-4

7. Porrini C, Celli G, Radeghieri P, Marini S, Maccagnani B. Studies on the use of honeybees (Apis mellifera L.) as bioindicators of metals in the environment. Insect Soc Life 2000;3:153-9.

8. Yazgan S, Horn H, Isengard HD. Honey as bioindicator by screening the heavy metal content of the environment Deutsche Lebensmittel-Rundschau 2006;102:192-7.

9. Pisani A, Protano G, Riccobono F. Minor and trace elements in different honey types produced in Siena County (Italy) Food Chem 2008;107:1553-60. doi: 10.1016/j. foodchem.2007.09.029

10. Conti ME, Botre F. Honeybees and their products as potential bioindicators of heavy metal contamination. Environ Monit Assess 2001;69:267-82. doi: 10.1023/A:1010719107006

11. Naccari C, Macaluso A, Giangrosso G, Naccari F, Ferrantelli V. Risk assessment of heavy metals and pesticides in honey from Sicily (Italy). J Food Res 2014;3:107-17. doi: 10.5539/ jfr.v3n2p107

12. Devillers J, Pham-Delegue MH. Honey Bees: Estimating the Environmental Impact of Chemicals. London, New York: Taylor and Francis; 2002.

13. Bogdanov S. Contaminants of bee products. Apidologie 2006;37:1-18. doi: 10.1051/apido:2005043

14. Buldini PL, Cavalli S, Mevoli A, Sharma JL. Ion chromatographic and voltammetric determination of heavy and transition metals in honey. Food Chem 2001;73:487-95. doi: 10.1016/S0308-8146(01)00132-7

15. Fisher IJ, Pain DJ, Thomas VG. A review of a lead poisoning from ammunition sources in terrestrial birds. Biol Conservation 2006;131:421-32. doi: 10.1016/j. biocon.2006.02.018

16. Pain DJ, Carter I, Sainsbury AW, Shore RF, Eden P, Taggart MA, Konstantinos S, Walker LA, Meharg AA, Raab A. Lead contamination and associated disease in captive and reintroduced red kites Millvus milvus in England. Sci Total Environ 2007;376:116-27. doi: 10.1016/j. scitotenv.2007.01.062

17. Buekers J, Steen Redeker E, Smolders E. Lead toxicity to wildlife: derivation of a critical blood concentration for wildlife monitoring based on literature data. Sci Total Environ 2009;407:3431-8. doi: 10.1016/j.scitotenv.2009.01.044

18. Montazer-Rahmati MM, Rabbani P, Abdolali A, Keshtkar AR. Kinetics and equilibrium studies on biosorption of cadmium, lead, and nickel ions from aqueous solutions by intact and chemically modified brown algae. J Hazard Mater 2011;185:401-7. doi: 10.1016/j.jhazmat.2010.09.047

19. Mahmoudi R, Mardani K, Rahimi B. Analysis of heavy metals in honey from north-western regions of Iran. J Chem Health Risk 2015;5:251-6.

20. Directive 96/77/EC of the European Commission of 2 December 1996 laying down specific purity criteria on food additives other than colours and sweeteners [displayed 5 July
2016]. Available at http://ec.europa.eu/food/fs/sfp/addit flavor/flav14_en.pdf

21. Council Regulation (EC) No 1804/1999 of 19 July 1999 supplementing Regulation (EEC) No 2092/91 on organic production of agricultural products and indications referring thereto on agricultural products and foodstuffs to include livestock production. Chapter: Beekeeping and Beekeeping products. Off J Europ Comm 1999;L222:C [displayed 5 July 2016]. Available at http://eur-lex.europa.eu/legal-content/ E N / T X T / H T M L / ? u r i=C E L E X: $31999 \mathrm{R} 18$ $04 \&$ qid $=1467713974318 \&$ from $=$ en

22. European Commission (EC). Opinion of the scientific committee on veterinary measures relating to public health on honey and microbiological hazards 2002; adopted 19-20 June 2002 [displayed 5 July 2016]. Available at http://www2. esb.ucp.pt/twt/seg_alim/outros/Mel=perigos microbiologicos.pdf

23. European Food Safety Authority (EFSA). Scientific opinion of the panel on food additives, flavourings, processing aids and materials in contact with food (AFC) (Question No EFSA-Q-2006-021) Adopted on 27 November 2007. EFSA J 2007;615:1-28.

24. Ravoet J, Reybroeck W, de Graaf DC. Pesticides for apicultural and/or agricultural application found in Belgian bee wax combs. Bull Environ Contam Toxicol 2015;94:5438. doi: 10.1007/s00128-015-1511-y

25. Formicki G, Gren A, Stawarz R, Zysk B, Gal A. Metal content in honey, propolis, wax, and bee pollen and implications for metal pollution monitoring. Pol J Environ Stud 2013;22:99106.

26. Svečnjak L, Baranović G, Vinceković M, Prđun S, Bubalo D, Tlak Gajger I. An approach for routine analytical detection of beeswax adulteration using FTIR-ATR spectroscopy. J Apicult Sci 2015;59:37-49. doi: 10.1515/jas-2015-0018

27. Leita L, Muhlbachova G, Cesco S, Barbattini R, Mondini C. Investigation of the use of honeybees and honeybee products to assess heavy metals contamination. Environ Monit Assess 1996;43:1-9. doi: 10.1007/BF00399566

28. Porrini C, Ghini S, Girotti S, Sabatini AG, Gattavecchia E, Celli G. Use of honey bees as bioindicators of environmental pollution in Italy. In: Devillers J, Pham-Delegue MH, editors. Honey bees: Estimating the environmental impact of chemicals. London, New York: Taylor and Francis; 2002.

29. Bilandžić N, Gačić M, Đokić M, Sedak M, Ivanec Šipušić $Ð$, Končurat A, Tlak Gajger I. Major and trace elements levels in multifloral and unifloral honeys in Croatia. J Food Comp Anal 2014;33:132-8. doi: 10.1016/j.jfca.2013.12.002

30. Wu JY, Anelli CM, Sheppard WS. Sub-lethal effects of pesticide residues in brood comb on worker honey bee (Apis mellifera) development and longevity. PLoS One 2011; 6:e14720. doi: 10.1371/journal.pone.0014720

31. Wu JY, Smart MD, Anelli CM, Sheppard WS. Honey bees (Apis mellifera) reared in brood combs containing high levels of pesticide residues exhibit increased susceptibility to Nosema (Microsporidia) infection. J Invertebr Pathol 2012;109:326-9. doi: 10.1016/j.jip-2012.01.005

32. Rangel J. The effects of miticides on the mating health of honey bee (Apis mellifera L.) queens. In: Proceedings of XXXXIII Apimondia International Apicultural Congress; 29 Sep - 4 Oct 2013; Kyiv, Ukraine. p. 187.

33. Collins AM, Pettis JS. Correlation of queen size and spermathecal contents and effects of miticide exposure during 
development. Apidologie 2013;44:351-6. doi: 10.1007 s13592-012-0186-1

34. Rashed MN, El-Haty MTA, Mohamed SM. Bee honey as environmental indicator for pollution with heavy metals. Toxicol Environ Chem 2009;91:389-403. doi: $10.1080 / 02772240802294870$
35. Abon-Shaara HF. The foraging behaviour of honey bees, Apis mellifera: a review. Veterinarni Medicina 2014;59:1-10.

36. Reddy DHK, Lee S-M, Seshaiah K. Biosorption of toxic heavy metal ions from water environment using honeycomb biomass-an industrial waste material. Water Air Soil Pollut 2012;223:5967-82. doi: 10.1007/s11270-012-1332-0

Koncentracije olova, kadmija, arsena i žive tijekom prerade pčelinjeg voska metodom lijevanja

U intenzivnom modernom načinu pčelarenja satne su osnove nužan materijal. Teški metali mogu se taložiti u satnim osnovama tijekom više desetljeća, a uobičajena je pčelarska praksa kontinuirano prerađivati vosak. Uzorci pčelinjeg voska analizirani su GFAAS-om za utvrđivanje koncentracija $\mathrm{As}, \mathrm{Cd}, \mathrm{Pb}$ i $\mathrm{Hg}$ tijekom proizvodnje satnih osnova primjenom tehnologije lijevanja s produženom fazom hlađenja i sedimentacije. Utvrđene su značajne razlike u koncentracijama As, $\mathrm{Cd}, \mathrm{Pb}(\mathrm{p}<0,01 ;$ svi) i Hg $(\mathrm{p}<0,05)$ između triju izdvojenih slojeva voska u čeličnim spremnicima dvostrukih stijenkâ $\mathrm{i}$ satnim osnovama tijekom prerade voska. Koncentracije $(\mathrm{mg} / \mathrm{kg})$ pretraživanih metala u satnim osnovama kao konačnom proizvodu utvrđene su u rasponu: As 0,01-0,88; Cd 1,26-3,55; Pb 82,5-171 i Hg 0,29-1,46. Najniže koncentracije pretraživanih elemenata utvrđene su u slojevima materijala za izradu satnih osnova kao konačnog proizvoda, a najviše u istaloženom sloju otpada. Dobiveni rezultati upućuju na mogućnost da se primjenom opisane metode mogu učinkovito ukloniti značajne količine teških metala iz sirovine voska korištenog za preradu u nove satne osnove. 